\title{
Rereading A Literature of Their Own: British Women Novelists From Brontë to Lessing*
}

\author{
LI Rui \\ BU Yu-wei \\ Shandong University (Weihai), Weihai, China \\ Harbin Institute of Technology (Weihai), Weihai, China
}

\begin{abstract}
Elaine Showalter's A Literature of Their Own: British Women Novelists From Brontë to Lessing is a pioneering masterpiece in feminism studies. The book impresses the reader with Showalter's groundwork to revive the interest in long-forgotten women writers in British literature history. Showalter's work is indeed a kind of rediscovery, mapping widely rather than mining deeply the territory of women's writing. In a sense, feminist criticism came of age with this book.
\end{abstract}

Keywords: Elaine Showalter, A Literature of Their Own: British Women Novelists from Bronte to Lessing, feminism

\section{Introduction}

Elaine Showalter (1941) is one of the most influential American scholars in the field of feminine studies. $A$ Literature of Their Own: British Women Novelists From Brontë to Lessing which was published first in 1977 and whose expanded edition came out in 1999 is Showalter's break-out work. This book is a pioneering masterpiece for feminist critics.

In her introduction to A Literature of Their Own Showalter says:

In the atlas of the English novel, women's territory is usually depicted as a desert bounded by mountains on four sides: the Austen peaks, the Brontë cliffs, the Eliot range and the Woolf hills. This book is an attempt to fill in the terrain between these literary landmarks and to construct a more reliable map from which to explore the achievements of English women novelists. (p. iii)

The book which follows admirably fulfills this plan by outlining the contours and circumstances of its authors' careers as well as their lives. In addition, it summarizes and classifies scores of minor writers-all widely known in their times but forgotten now. In the course of this survey, we get a succinct social history of middle class 19th and early 20th century England.

\section{A Survey of the Book}

Taking her title from an observation of John Stuart Mill in 1869- "If women lived in a different country from men and had never read any of their writings, they would have a literature of their own" (Mill, 1970, p. 207) - Showalter suggests that women themselves were slowly growing aware of their separateness and leaving

\footnotetext{
* Acknowledgements: The paper is one of the research findings of the project "Stage Presentation of Western Classic Drama in China" (No. J12WE70) which is sponsored by the Humanities and Social Project for College and University in Shandong.

LI Rui, instructor, master, School of Translation Studies, Shandong University (Weihai).

BU Yu-wei, instructor, master, School of Languages and Literature, Harbin Institute of Technology (Weihai).
} 
a record of that awareness in their works. It is the growth of a collective self-consciousness-the history of a distinct literary subculture - that $A$ Literature of Their Own sets out to record.

Showalter contends that all literary subculture can be traced through three major phases: first a phase of "imitation" and "internalization" in which the subculture largely adopts the values and the literary forms of the dominant tradition - a phase which here extends from the widespread appearance of the male pseudonym in the 1840 s to the death of Gorge Eliot in 1880; next a phase of "advocacy" and "protest" in which the subculture rejects prevailing values and begins to declare its autonomy — a stage which Showalter associates with the years between 1880 and the winning of the vote in 1920; and finally a phase of "self-discovery" — a turning inward and a search for identity — which here begins around 1920 and continues to the present. Having survived a culture's equivalent of childhood and adolescence, Showalter's model implies that the female literature tradition now approaches its maturity.

Showalter labels these stages of development the "feminine", the "feminist", and the "female". These problematic names have provoked a hot discussion among critics. Ruth Yeazell argues that "feminine is a word difficult to associate with the massive achievement of the Brontës, Gorge Eliot, and Mrs. Gaskell” (Yeazell, 1978, p. 282). Although these words are ambiguous in academic meanings, they can never reduce this book's value.

What Showalter gives us is not the single life-history of British women writers, but a perceptive and wide-ranging family chronicle. One of the pleasures of reading A Literature of Their Own lies in discovering previously forgotten branches of the family, in tracing hitherto buried lines of kinship and inheritance. Showalter suggests that we have failed to sense such connections before can be partly attributed to our insistent concentration on the extraordinary few, such as George Eliot and Virginia Woolf. Showalter recovers for us many of more ordinary ones - sensation novelists like Mary Braddon, Rhoda Broughton; feminist like Olive Schreiner and Sarah Grand; suffragettes and radicals like Elizabeth Robins and Dora Marsden. A Literature of Their Own is illuminating and richly informative. To follow the account of Braddon's Lady Audley as she pushes her husband down a well or of Robin's militant heroine, Vida Levering, as she blackmails her Parliamentary ex-lover into backing the suffrage bill by threatening to seduce his new fiancée into the women's movement is to share Showalter's delight in the narrative exuberance of the female imagination. To see the direct kinship between the murderous wives of sensation fiction and Eliot's deadly Madame Laure in Middlemarch is to recognize anew the way in which great art feeds and thrives on the not-so-great.

However, most Victorian novels were restrained by the conventions of sexual behavior except for their murder plots. Even the sensationalists of the 60 s never gave full development of their lurid fantasies of escape and revenge. "By the second volume guilt has set in. In the third volume we see the heroine punished, repentant, and drained of all energy" (Showalter, 2004, p. 180). But Showalter still believes that the very constraints under which the Victorians labored produced novels that ironically seem richer and more satisfying than many that followed. "The repression in which the feminine novel was situated...forced women to find innovative and convert ways to dramatize the inner life, and led to a fiction that was intense, compact, symbolic, and profound" (Showalter, 2004, pp. 27-28). Beginning with the writers of the 80s and 90s, Showalter finds in these novelists the disturbing signs of evasion, retreat and the defensive maneuvers of denying the full truth of women's experience. It is as if the lifting of repression left women terrified by their own once-buried impulses and desires. While the Victorians could compose fiction that explicitly affirmed the social order half-consciously, their successors responded to new freedom by producing a literature of anxiety and flight. 
Though the modes of evasion vary from time to time, the image of a narrowly enclosed female space haunts in Showalter's book. The typical case here is naturally Virginia Woolf's A Room of One's Own. In the chapter on Woolf, Showalter (2004) launches a fight to destroy the modern Angel in the Bloomsbury House:

I think it is important to demystify the legend of Virginia Woolf. To borrow her own murderous imagery, a woman writer must kill the Angel in the House, that phantom of female perfection who stands in the way of freedom. For Charlotte Brontë and George Eliot, the Angel was Jane Austen. For the feminist novelists, it was George Eliot. For mid-twentieth-century novelists, the Angel is Woolf herself. (p. 265)

If Showalter seems tolerant of remote literary ancestors, she ultimately decides to break the bondage of female repression by subverting the icon status of Woolf. Showalter harbors the fear that Woolf-worship has already become a cult to some extent with the vague notion of "androgyny" invoked as its major faith. In such a context, it is intellectually valuable to discover the limits of Woolf's vision-the peculiar impersonality and sexlessness of her world. The celebration of androgyny, Showalter argues, was Woolf's way of denying her own sexuality and of the fleeing life itself. Woolf's androgynous ideal is a repressive flight from the realities of being a woman and an inhuman attempt to transcend the body.

Yet if Woolf's idea can be "deadly" and "disembodied" (Showalter, 2004, p. 297), Showalter's exploration on Woolf focuses on the person and the flesh on the contrary. Speculating on Woolf's anxieties about menstruation, childbirth, menopause, and her jealousy of Vanessa and her rage against Leonard, the chapter is a document of Woolf's inadequacies not as an artist but as a woman. Though Showalter intentionally responds to the current idealization of Woolf's life, though her psychological argument is often stimulating and persuasive, Showalter leaves out Woolf's novels when she composes this chapter. Showalter offers the conflicts and failures of a novelist's personal history as the principal measure of her achievement. This approach seems to lack academic power.

\section{A Look Into the New Edition}

Showalter could have the opportunity to strengthen her academic weakness when the expanded edition of A Literature of Their Own came out in 1999. But it seems that she misses this chance. After rethinking 20 years' acceptance of and discussion about the book, Showalter adds a new introduction "Twenty Years On: A Literature of Their Own Revisited" and a new conclusion "Laughing Medusa". Toril Moi reveals Showalter's untheorized assumptions in 1980s. Showalter writes back in the defensive introduction to the expanded edition by affirming that "the disciplines with answers for such questions were not philosophy and linguistics, but cultural anthropology and social history" (Showalter, 2004, p. xiv). Whether this simple declaration can satisfy Moi or not matters little to the present readers. The moment for A Literature of Their Own was the spring time of feminist criticism in the 1970s when scholars who just had begun women's writing research were looking for professional guidance as Showalter offered. But the 1990s has witnessed the full development of feminist studies for which this book is no more than a history. Showalter's fighting old battles, particularly with Toril Moi whose Sexual/Textual Politics is also an old book (1985), seems a kind of unnecessary self-wounding which betrays the valor of her cause.

One of the aims of A Literature of Their Own is to show how the development of female literary tradition is similar to the growth of any literary subculture. When the academic world is anticipating eagerly to see Showalter to deepen and sharpen her original thoughts in the expanded edition in the light of recent theories, Showalter just offers them an added chapter on important British novelists who have flourished since the book 
was published. Showalter draws the history of British women novelists in the 20th century in broad stroke. She traces the continuity of the Victorian tradition in British women's novels up the present, but the emphasis on particular coherences and continuities in the literary tradition means that other continuities or the discontinuous effects of significant social upheavals and movements cannot be explored, including major conflicts and debates among 20th century feminists.

Moreover, this chapter is largely a discussion of Angela Carter and Showalter invokes her as the spirit of the new age. In the works of Angela Carter, Showalter reads the triumphant figure as both the transcendence of the female heritage which she once feared to hobble British women's writing and women's energized participation in a post-modern mainstream. Here Showalter breaks out the insularity of the British women's literature history and embraces the world. However, this dramatic shift from her early tragic portent to now comic celebration of being in the world feels too abrupt and perverse. The fact is British women writers have been very engaged in both the creation and contesting of nation and Empire. But disappointingly, Showalter sidesteps issues of gender, class, race, and nation in the new conclusion chapter.

\section{Conclusion}

A Literature of Their Own impresses the reader with Showalter's groundwork to revive the interest in long-forgotten women writers in British literature history. It is not her remarks on Brontës or George Eliot or Virginia Woolf that gives the book its enduring quality, but the range of its references to minor writers. Showalter's work is indeed a kind of rediscovery, mapping widely rather than mining deeply the territory of women's writing. Showalter, as her book's title indicates, has given women writers their own tradition. In a sense, feminist criticism came of age with this book. Whatever flaws the book may have, our debt to it is huge and should never be forgotten. A Literature of Their Own in many ways is an easy and energizing read. Its schematic certainties take hold of complex and devise materials. This masterpiece has nurtured women's writing and feminist criticism studies. It has stimulated research, prompted the publication of neglected women writers, and helped many young women go out to speak and act for themselves in the world.

\section{References}

Bray, J. (2009). The female reader in the English novel: From Burney to Austen. New York: Routledge.

Mill, J. S. (1970). Essays on sex equality. A. S. Rossi (Ed.). Chicago: The University of Chicago Press.

Ralph, P. C. (1989). Victorian transformations: Fairy tales, adolescence, and the novel of female development. Pieterlen: Peter Lang.

Showalter, E. (2004). A literature of their own: British women novelists from Brontë to Lessing. Beijing: Foreign Language Teaching and Research Press.

Yeazell, R. (1978). The female tradition. Novel: A Forum on Fiction, 11(3), 281-285. 